\title{
Effect of Plasma from Patients with Behçet's Disease on the Production of Nitric Oxide in Cultured Human Umbilical Vein Endothelial Cells
}

\author{
Asım Örem ${ }^{a}$ Murat Ertürk ${ }^{b}$ Gülseren Çimşit ${ }^{c}$ Birgül Vanizor Kural ${ }^{a}$ \\ Departments of aBiochemistry and bermatology, Faculty of Medicine, Karadeniz Technical University, Trabzon, \\ and ${ }^{c}$ Department of Microbiology, Faculty of Medicine, Ondokuz Mayıs University, Samsun, Turkey
}

\section{Key Words}

Behçet's disease • Nitric oxide · Human umbilical vein endothelial cells

\begin{abstract}
Objective: To determine the effect of plasma from patients with Behçet's disease (BD) on the production of nitric oxide (NO) in cultured human umbilical vein endothelial cells (HUVECs). Subjects and Methods: NO levels were measured in cell culture media after 24-hour incubation of the cells with plasma obtained from 22 BD patients and 16 age/sex-matched healthy control subjects. After treatment of the patients with colchicine and/ or nonsteroidal anti-inflammatory drugs, 12 of the patients were considered to be in the inactive phase of the disease. Levels of NO production were also measured in these 12 patients. In addition to the in vitro experiments, erythrocyte sedimentation rate, $\alpha_{1}$-antitrypsin, $\alpha_{2}$-macroglobulin and neutrophil counts were measured in the patients and controls. Results: Levels of NO in active state BD patients ( $15.9 \mu \mathrm{mol} / 10^{6}$ cells) were significantly lower than values obtained from both patients in the inactive period $\left(19.2 \mu \mathrm{mol} / 10^{6}\right.$ cells $)$ and the control group (19.7 $\mu \mathrm{mol} / 10^{6}$ cells). No significant differences
\end{abstract}

\begin{tabular}{ll}
\hline KARGER & ( ) 2004 S. Karger AG, Basel \\
1011-7571/04/0131-0035\$21.00/0 \\
$\begin{array}{l}\text { Fax +4161306 1234 } \\
\begin{array}{l}\text { E-Mail karger@karger.ch } \\
\text { www.karger.com }\end{array}\end{array}$ & $\begin{array}{l}\text { Accessible online at: } \\
\text { www.karger.com/mpp }\end{array}$
\end{tabular}

were observed in induced NO products between the patients in the inactive stage and control subjects. Conclusion: Plasma from BD patients decreased the level of NO production in the HUVECs, and therefore may cause dysfunction in the endothelial NO synthase activity.

Copyright $@ 2004$ S. Karger AG, Basel

\section{Introduction}

Behçet's disease, discovered by Dr. Hulusi Behçet [1] in 1937 , is characterized by multiple system involvement though vasculitis is perceived as the basic pathological process in the patients. Endothelial cells modify vascular tone and contribute to hemostasis of the blood coagulation system $[2,3]$. As described in previous studies, one of the most striking features of Behçet's disease is endothelial dysfunction, which is thought to be a major factor for increased frequency of thrombosis [4].

Endothelial cells produce many biological substances, including endothelin-1, nitric oxide (NO), prostaglandins and heparin, all of which play an important role in continuous vascular hemostasis. Many types of cells, including platelets, fibroblasts, neuronal cells, endothelial cells, macrophages and neutrophils produce NO through nitric
Prof. Dr. Asım Örem
KTÜ Tip Fakültesi
Biyokimya ABD
TR-61080 Trabzon (Turkey)
Fax +462 3252270, E-Mail aorem64@yahoo.com 
oxide synthase (NOS). NOS exists in three isoforms encoded by distinct genes: type I neuronal NOS, type II inducible NOS, and type III endothelial NOS (eNOS). All three forms are rapidly activated by intracellular $\mathrm{Ca}^{2+}$ fluxes and produce small quantities of NO. Both types I and III are $\mathrm{Ca}^{2+}$ calmodulin-dependent constitutive NOS isoforms that are rapidly activated by intracellular $\mathrm{Ca}^{2+}$ fluxes and produce small quantities of NO. Type II is a $\mathrm{Ca}^{2+}$-independent isoform that can be induced in large amounts by cytokines and endotoxins during inflammatory or infectious processes in many cells, including hepatocytes, macrophages, neutrophils, smooth muscle cells and chondrocytes. NO derived from eNOS has been implicated in a variety of biological processes such as relaxation of vascular smooth muscle cells, which causes vasodilatation and an anticoagulant effect $[5,6]$. On the other hand, it has been shown that oxidized low-density lipoprotein decreases the expression of eNOS [7].

In a previous study, we showed decreased levels of plasma NO end products, nitrite and nitrate in patients with Behçet's disease [8]. As mentioned above, the source of measured plasma NO products does not represent endothelial-derived NO synthesis. Therefore, the present in vitro study was conducted to assess the action of plasma from patients with Behçet's disease on the production of NO in cultured endothelial cells.

\section{Subjects and Methods}

\section{Subjects}

The study group included 22 patients with Behçet's disease (12 male and 10 female with a mean age of 33.5 years, range: $28-55$ years) and 16 sex/age-matched healthy volunteers. The diagnosis of Behçet's disease was made according to the criteria defined by the International Study Group for Behçet's Disease [9]. Oral aphthous lesions and genital ulcerations were present in 19 patients; uveitis was present in 5 patients. Thirteen patients were treated with colchicine, 3 with nonsteroidal anti-inflammatory drugs and 6 with colchicine plus nonsteroidal anti-inflammatory drugs. Since there is no clinically approved scoring system or laboratory screening profile to define the severity of Behçet's disease, the patients were classified as being in active or inactive disease states by physical manifestations (oral aphthous lesions, genital ulcers and ocular lesions) together with appropriate laboratory investigations, including erythrocyte sedimentation rate (ESR), neutrophil count, $\alpha_{1}$-antitrypsin and $\alpha_{2}$-macroglobulin levels. Patients were considered to be in the active stage of the disease if they had two or more of the following diagnostic criteria: oral aphthae, genital ulcers and uveitis. The disease was considered inactive if patients showed clinical improvement during therapy and had no further ocular attack, genital ulcerations or other manifestations by the end of a 1-year follow-up period. Thus, 10 patients were considered to be in the active phase of the disease and 12 were considered to be in the inactive phase.

\section{Determination of Active Phase Reactants}

Blood samples were drawn from the patients and controls in the morning following an overnight fast before and after treatment. None of the patients received systemic or topical therapy at least 4 weeks prior to blood collection. Blood samples of $2.5 \mathrm{ml}$ were drawn into collection tubes with EDTA $(1 \mathrm{mg} / \mathrm{ml})$ anticoagulant and an additional $2.5 \mathrm{ml}$ were drawn into tubes without anticoagulant. The blood samples with anticoagulant were divided into two aliquots. Neutrophil count and ESR were determined immediately in one aliquot. Neutrophils were counted by an automated blood counter (MaxM, Coulter), and ESR was determined by the classical Westergren method. The second aliquot was immediately stored at $-70^{\circ} \mathrm{C}$ and its serum was later used to measure $\alpha_{1}$-antitrypsin and $\alpha_{2}$-macroglobulin concentration in a Behring nephelometer 100 analyzer.

\section{Isolation and Culture of Endothelial Cells}

Primary cultures of human umbilical vein endothelial cells (HUVECs) were produced from 3-4 pooled freshly delivered umbilical cords $(20-40 \mathrm{~cm})$ obtained from healthy births. The endothelial cells were isolated by the method of Jaffe et al. [10], with minor modifications as suggested by Ashraff [11]. Briefly, the inner lining of the vessel was enzymatically digested with $0.2 \%$ collagenase (Sigma, Diesenhofen, Germany) for $6 \mathrm{~min}$ at $37^{\circ} \mathrm{C}$ in $5 \% \mathrm{CO}_{2}$. The endothelial cells of each cord were then mixed and seeded into tissue culture flasks of $24 \mathrm{~cm}^{2}$ (Greiner, Frickenhausen, Germany) for propagation in the presence of medium 199 (Biological Industries, Haemek, Israel) supplemented with $20 \%$ fetal calf serum (Sigma), $2 \mathrm{mM}$ glutamine, penicillin and streptomycin $(100 \mathrm{U} / \mathrm{ml}$ and $100 \mu \mathrm{g} / \mathrm{ml}$, respectively) and $2.5 \mu \mathrm{g} / \mathrm{ml}$ of Fungizone. The medium was renewed the following day and every other day until cells grown to confluence. In the first passage, HUVECs were dispersed with trypsin/EDTA and seeding at a split ratio of $1: 1$ in $0.2 \%$ gelatin-coated $25-\mathrm{cm}^{2}$ culture flasks. The cells at passages 3-4 were similarly harvested from the flasks and seeded into tissue culture dishes ( $35 \mathrm{~mm}$ in diameter). Preliminary experiments, in which the cell number per well was measured by hemacytometer, demonstrated that each well contained $10^{6}$ cells at full confluence. The Bradford protein assay [12] was used to confirm cell number consistency in each well, which resulted in $<5 \%$ variation. Experimental results were thus expressed as per $10^{6}$ cells.

\section{Treatment of Cells with Plasma}

The effects of different plasma samples on NO synthesis were studied by adding individual plasma samples in duplicates into cell culture wells at a final concentration of $2 \%$ in $1-\mathrm{ml}$ culture medium. Before incubation of the cells, plasma was heparinized $(500 \mathrm{U} / \mathrm{ml})$ to prevent clotting with EDTA when exposed to the endothelial cells [13]. After 24-hour incubation of endothelial cells with plasma samples taken from patients or control subjects, each culture medium was collected and deproteinized to measure the by-products of NO synthesis. After reduction of nitrite (using iodide and acetic acid) and of nitrate (using vanadium III and hydrochloric acid) at $90^{\circ} \mathrm{C}$ into liquid, an inert gas was used to purge NO from the solution. The resulting peak NO levels were then detected by chemiluminescence using the Sievers NO chemiluminescence analyzer (model 280, Boulder, USA) [14]. The amount of NO in the sample was proportional to the amount of light emitted and was calculated using a standard curve. 
Statistical Analysis

Results were expressed as median and range. Plasma concentrations of acute phase reactants and NO products in patients and control subjects were compared by the Mann-Whitney U test. The Wilcoxon test was used to compare the results in the active and inactive phases of the disease; $p<0.05$ was considered statistically significant.

\section{Results}

The levels of NO metabolites measured in the endothelial cell cultures incubated by the plasma samples of patients with Behçet's disease were found to be significantly lower than in the healthy controls (table 1). Ten of the 22 patients with active period of the disease were still active period of the disease after the treatment and the rest of the patients were considered to be in the inactive period of the disease. The level of NO metabolites in the active phase $\left(16.0 \mu \mathrm{mol} / 10^{6}\right.$ cells $)$ was lower than that from patients in the inactive state $\left(19.2 \mu \mathrm{mol} / 10^{6}\right.$ cells, table 1). Interestingly, the level of NO products in the patients considered to be in the inactive phase was equal to that of the controls. The biochemical parameters (table 2) in all patients were generally higher than those of controls and the patients in the inactive phase, and the differences were statistically significant $(p<0.05)$.

\section{Discussion}

In a previous study, we reported that the levels of plasma NO metabolites in patients with active Behçet's disease were lower than normal [8]. This finding may not necessarily imply functional impairment of vascular en- dothelium because the source of NO metabolites in the circulation may vary. The present study, conducted to demonstrate the role of endothelial cells in NO metabolite production when incubated in an appropriate medium, showed that the level of NO metabolites was lower in all BD patients than in patients in the inactive stage or the controls, consistent with previous studies $[3,4,15,16]$ that have described endothelial dysfunction in patients with Behçet's disease. It is plausible that increased free radical production through oxidative stress, as occurs in Behçet's disease, might be involved in events leading to suppression of eNOS activity in endothelial cells [17-19]. Additionally, Liao et al. [7] reported that oxidized low-density lipoprotein regulates eNOS expression through a combination of early transcriptional inhibition and transcriptional mRNA destabilization [7], supporting our previous observations that plasma autoantibodies against oxidized low-density lipoprotein are high in Behçet's disease [20].

Table 1. Levels of NO products in the cultured endothelial cells incubated with plasma from patients with Behçet's disease and controls

\begin{tabular}{lll}
\hline & \multicolumn{2}{l}{$\begin{array}{l}\text { NO products } \\
\mu \text { mol/106 cells }\end{array}$} \\
\cline { 2 - 3 } & median & range \\
\hline All subjects with Behçet's disease $(\mathrm{n}=22)$ & 15.9 & $14.9-17.2^{*}$ \\
$\quad$ Active phase $(\mathrm{n}=10)$ & 16.0 & $15.2-17.5$ \\
$\quad$ Inactive phase $(\mathrm{n}=12)$ & 19.2 & $17.3-22.0$ \\
Controls $(\mathrm{n}=16)$ & 19.7 & $17.9-21.6$ \\
\hline
\end{tabular}

$* \mathrm{p}<0.05$

Table 2. Levels of biochemical parameters in all patients with Behçet's disease and controls

\begin{tabular}{|c|c|c|c|c|}
\hline & $\begin{array}{l}\text { Total patients with } \\
\text { Behçet's disease } \\
(\mathrm{n}=22)\end{array}$ & $\begin{array}{l}\text { Patients in the } \\
\text { active phase } \\
(\mathrm{n}=10)\end{array}$ & $\begin{array}{l}\text { Patients in the } \\
\text { inactive phase } \\
(n=12)\end{array}$ & $\begin{array}{l}\text { Controls } \\
(n=16)\end{array}$ \\
\hline Neutrophils, $10^{3} / \mathrm{ml}$ & $5.1(3.0-8.7)$ & $5.2(3.1-8.4)^{*}$ & $3.1(1.4-4.1)$ & $2.4(1.5-4.3)^{* *}$ \\
\hline$\alpha_{1}$-Antitrypsin, mg/dl & $215(158-315)$ & $230(161-317)^{*}$ & $143 \quad(98-181)$ & $125 \quad(95-172)^{* *}$ \\
\hline$\alpha_{2}$-Macroglobulin, mg/dl & $245(179-344)$ & $278(202-353)^{*}$ & $200(133-286)$ & $154(117-201)^{* *}$ \\
\hline $\mathrm{ESR}, \mathrm{mm} / \mathrm{h}$ & $28.1(9.6-72)$ & $30.8(8.4-57)^{*}$ & $18.0(7.6-31.6)$ & $9.4(2.1-17.6)^{* *}$ \\
\hline
\end{tabular}

\footnotetext{
* Significantly different from the patients in the inactive period, according to the Wilcoxon test $(\mathrm{p}<0.05)$.

** Significantly different from total patients with Behçet's disease, according to the Mann-Whitney U test $(\mathrm{p}<0.05)$.
} 
The possibility of a genetic disorder being involved in the decreased eNOS level in patients with Behçet's disease can be ruled out since the levels of NO metabolites in control subjects and patients with Behçet's disease in the inactive state were not different. Thus, the functional impairment of endothelial cells may be related to secondary pathological events that only develop in the active phase of the disease. Indeed, it is likely that the degree of locally affected eNOS activity may play a critical role in the development of vascular thrombotic events seen in about one third of the patients with Behçet's disease [21]. While, in the present study, the plasma from patients with Behçet's disease decreased the level of NO production in HUVECs (suggesting dysfunction in the endothelial NO synthase activity), further study to show histochemical eNOS activity on biopsy materials obtained from patients with Behçet's disease in active and inactive phases could provide more definitive explanatory information on functionally impaired endothelial NO production.

\section{Conclusion}

The findings of this study indicate that plasma from patients with Behçet's disease decreased the level of NO production in the HUVECs, and therefore may cause dysfunction in the endothelial NO synthase activity.

\section{Acknowledgments}

The authors would like to thank Prof. Dr. Deniz Erbas (Gazi University, Ankara) for measurement of nitric oxide in nitric oxide chemiluminescence analyzer (NOA).

This work was supported by Karadeniz Technical University Research Fund (98.114.001.11).

\section{References}

1 Behçet H: Über rezidivierende Aphthose: Durch ein Virus verursachte Geschwüre am Mund, am Auge und an den Genitalien. Dermatol Wochenschr 1937;105:1152.

2 Samlaska CP, James WD: Superficial thrombophlebitis. II. Secondary hypercoagulable states. J Am Acad Dermatol 1990;23:1-18.

3 Hampton KK, Chamberlain MA, Menon DK, Davies JA: Coagulation and fibrinolytic activity in Behçet's disease. Thromb Haemost 1991; 66:292-294.

4 Schmitz-Huebner U, Knop J: Evidence for endothelial cell dysfunction in associated with Behçet's disease. Thromb Res 1984;34:277285.

5 Lincoln J, Hoyle CHV, Burnstock G (eds): Nitric Oxide in Healthy and Disease. Cambridge, Cambridge University Press, 1997, pp 27-41.

6 Farrell AJ, Blake DR: Nitric oxide. Ann Rheum Dis 1996;55:7-20.

7 Liao JK, Shin WS, Lee WY, Clark SL: Oxidized low-density lipoprotein decreases the expression of endothelial nitric oxide synthase. $\mathbf{J}$ Biol Chem 1995;270:319-324.

8 Örem A, Vanizor B, Çimşit G, Kıran E, Deger O, Malkoç M: Decreased nitric oxide production in patients with Behçet's disease. Dermatology 1999;198:33-36.
9 International Study Group for Behçet's Disease: Criteria for diagnosis of Behçet's disease. Lancet 1990;335:1078-1080.

10 Jaffe EA, Nachman RL, Becker CG, Minick CR: Culture of endothelial cells derived from umbilical veins: Identification by morphologic and immunologic criteria. J Clin Invest 1973; 52:2245-2756.

11 Ibrahim AS: Personal communication. HarborUCLA Research and Education Institute, Torrance, Calif., USA. Ibrahim@afp76.humc.edu.

12 Bradford MM: A rapid and sensitive method for quantitation of microgram quantities of protein utilizing the principle of protein dye binding. Ann Biochem 1976;72:248-254.

13 Devidge ST, Baker PN, Roberts JM: NOS expression is increased in endothelial cells exposed to plasma from women with preeclampsia. Am J Physiol Heart Circ Physiol 1995;38: H1106-H1112.

14 Ding Y, Vaziri ND: Calcium channel blockade enhances nitric oxide synthase expression by cultured endothelial cells. Hypertension 1998; 32:718-723.

15 Haznedaroglu IC, Ozcebe OI, Ozdemir O, Celik I, Dundar SV, Kirazli S: Impaired haemostatic kinetics and endothelial function in Behçet's disease. J Intern Med 1996;240:181-187.
16 Direskeneli H, Keser G, D’Cruz D, Khamashta MA, Akoglu T, Yazici H, Yurdakul S, Hamuryudan V, Ozgun S, Goral AJ: Anti-endothelial cell antibodies, endothelial proliferation and von Willebrand factor antigen in Behcet's disease. Clin Rheumatol 1995;14:55-61.

17 Yoshida T, Tanaka M, Sotomatsu A, Okamoto K, Hirai S: Serum of Behçet's disease enhances superoxide production of normal neutrophils. Free Radic Res 1998;28:39-44.

18 Dogan P, Tanrikulu G, Soyuer U, Kose K: Oxidative enzymes of polymorphonuclear leucocytes and plasma fibrinogen, ceruloplasmin, and copper levels in Behçet's disease. Clin Biochem 1994;27:413-418.

19 Örem A, Efe H, Deger O, Çimşit G, Uydu HA, Vanizor B: Relationship between lipid peroxidation and disease activity in patients with Behçet's disease. J Dermatol Sci 1997;16:1116.

20 Örem A, Çimşit G, Deger O, Vanizor B, Karahan SC: Autoantibodies against oxidatively modified low-density lipoprotein in patients with Behçet's disease. Dermatology 1999;198: 243-246.

$21 \mathrm{Li} \mathrm{H}$, Forstermann U: Nitric oxide in the pathogenesis of vascular disease. J Pathol 2000; 190:244-254 